\title{
Fuel Cells: Spectroscopic Studies in the Electrocatalysis of Alcohol Oxidation
}

\author{
Teresa Iwasita \\ Instituto de Química de São Carlos, Universidade de São Paulo, CP 780, 13566-590 São Carlos - SP, Brazil
}

\begin{abstract}
Métodos spectroscópicos modernos são úteis na elucidação de mecanismos eletroquímicos complexos, como os que ocorrem durante a oxidação de pequenas moléculas orgânicas $\left(\mathrm{CH}_{3} \mathrm{OH}\right.$, $\mathrm{HCOH}, \mathrm{HCOOH})$. Neste trabalho apresentamos o uso de métodos espectroscópicos para o estudo da oxidação de álcoois em eletrodos de platina ou binários principalmente constituídospor Pt. Estas reações são importantes para o desenvolvimento de sistemas anódicos em células a combustível. Espectrometria de massa e Espectroscopia de infra-vermelho FT permitem estabelecer os intermediários e produtos de reação, bem como a dependência da quantidade das espécies no potencial aplicado. FTIR e microscopia de tunelamento por varredura contribuem para o entendimento dos efeitos da estrutura de superfície na velocidade de reação. Exemplos da oxidação do etanol e metanol são apresentados em catalisadores de platina puros e modificados.
\end{abstract}

Modern spectroscopic methods are useful for elucidating complex electrochemical mechanisms as those occurring during the oxidation of small organic molecules $\left(\mathrm{CH}_{3} \mathrm{OH}, \mathrm{HCOH}, \mathrm{HCOOH}\right)$. In the present paper it is shown the use of spectroscopic methods to study the oxidation of alcohols on platinum or Pt-based binary electrodes. These reactions are of importance in conexion with the development of anode systems for use in fuel cells. Mass spectrometry and FT infrared spectroscopy allow to establishing the reaction intermediates and products and the dependence of the amount of species on the applied potential. FTIR and scanning tunneling microscopy contribute to understand the effects of the surface structure on the rate of reaction. Examples are presented for methanol and ethanol oxidation at pure and modified Pt catalysts.

Keywords: electrocatalysis, spectroscopic methods, fuel cells, alcohol oxidation, small organic molecules

\section{Introduction}

At present, one of the main goals in the research of energy converters is the development of a fuel cell for vehicle propulsion. A fuel cell (FC) is a device where the energy of fuels such as hydrogen, alcohols or hydrocarbons is converted into electricity. ${ }^{1,2}$

The principle of a FC function is illustrated in Figure 1, for a $\mathrm{CH}_{3} \mathrm{OH} / \mathrm{O}_{2}$ fuel cell. The fuel, $\mathrm{CH}_{3} \mathrm{OH}$ and $\mathrm{H}_{2} \mathrm{O}$ are continuously fed in the anode compartment. The mixture is converted to $\mathrm{CO}_{2}$ on the surface of the metal catalyst. The oxidant, oxygen (or air) enters in contact with a cathode and is reduced to water. Protons move from the anode to the cathode in the electrolyte which, in the modern cells (Polymer Electrolyte Fuel Cell, PEFC), is a proton conducting polymer, $\left(\mathrm{Nafion}^{\circledR}\right)$. Electrons flow in the external circuit to the load and the total reaction

* e-mail: iwasita@iqsc.sc.usp.br occurring is $\mathrm{CH}_{3} \mathrm{OH}+\mathrm{H}_{2} \mathrm{O} \rightarrow \mathrm{CO}_{2}+6 \mathrm{H}^{+}+6 \mathrm{e}$. For the anode, the best material known at present is a PtRu alloy. The cathode catalyst in acid fuel cells is platinum. During the cell operation some heat is produced, which can be

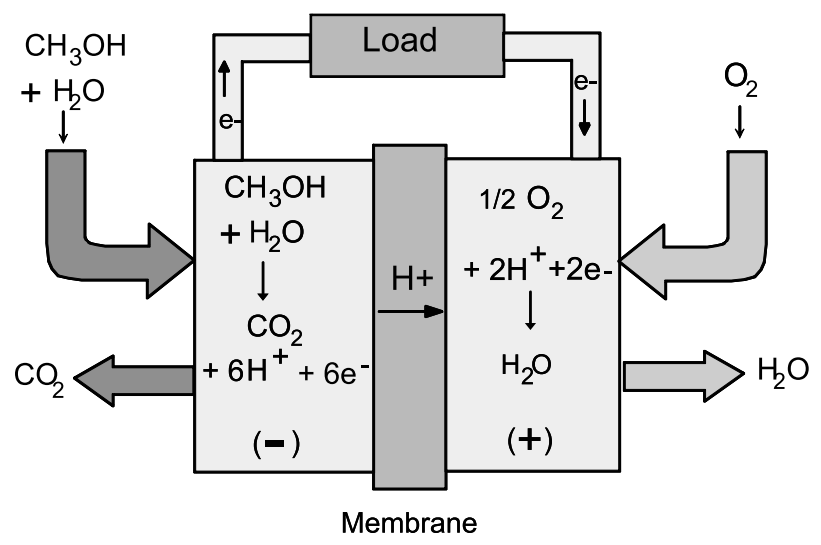

Figure 1. Schematic representation of a methanol fuel cell with polymer electrolyte. 
used to increase the temperature of the system thus improving the cell performance.

Fuel cells are distinguished from other batteries, by the fact that the active substances are continuously introduced in the system so that the cell can work without being limited by exhaustion of the reactants as it happens with other batteries.

As mentioned above, other fuels such as ethanol or hydrocarbons are thinkable as candidate substances for the anode reaction. However, at present, the $\mathrm{H}_{2} / \mathrm{O}_{2} \mathrm{FC}$ is the only FC working satisfactorily. This cell is being used in several applications including its use in commercial electric cars. This reflects the fact that hydrogen oxidation reaction has a good performance at Pt electrodes. On the contrary, hydrocarbons are very difficult to oxidize at low (room) temperature on all the known catalysts and alcohols present also relatively high overpotentials at Pt. Figure 2 illustrates this problem, by comparing the potential-time response of $\mathrm{H}_{2}\left(\mathrm{E}^{\circ}=0.0 \mathrm{~V}\right)$ and $\mathrm{CH}_{3} \mathrm{OH}\left(\mathrm{E}^{\circ}=0.02 \mathrm{~V}\right)$ to a $5 \mathrm{~mA}$ constant current signal. While the potential for methanol oxidation rapidly grows to a high value ( $c$. $550 \mathrm{mV})$, only a very low overpotential is observed for $\mathrm{H}_{2}$ oxidation. The problems involved in alcohol oxidation can be understood by considering the complex process occurring at the electrode surface. At first a dissociative adsorption takes place in successive steps: ${ }^{3}$

$$
\begin{aligned}
& \mathrm{CH}_{3} \mathrm{OH} \rightarrow \mathrm{CH}_{2} \mathrm{OH}+\mathrm{H}^{+}+\mathrm{e}^{-} \\
& \underset{x}{\mathrm{CH}_{2}} \mathrm{OH} \rightarrow \underset{\mathrm{xx}}{\mathrm{CHOH}}+\mathrm{H}^{+}+\mathrm{e}^{-} \\
& \underset{\mathrm{xx}}{\mathrm{CHOH}} \rightarrow \underset{\mathrm{xxx}}{\mathrm{COH}}+\mathrm{H}^{+}+\mathrm{e}^{-} \\
& \mathrm{COH} \rightarrow \underset{\mathrm{C}}{\mathrm{C}} \mathrm{O}+\mathrm{H}^{+}+\mathrm{e}^{-}
\end{aligned}
$$

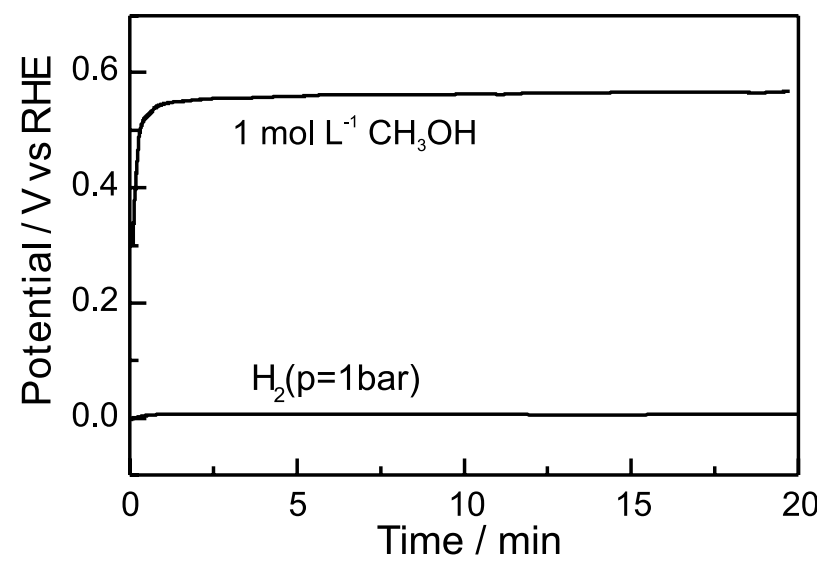

Figure 2. Potential-time responses for a platinized platinum electrode in $0.5 \mathrm{~mol} \mathrm{~L}^{-1} \mathrm{H}_{2} \mathrm{SO}_{4}$ after application of a $5 \mathrm{~mA}$ signal in the presence of $1.0 \mathrm{~mol} \mathrm{~L}^{-1} \mathrm{CH}_{3} \mathrm{OH}$ or $1 \mathrm{bar}_{2}$ as indicated on the respective curves. ${ }^{2}$ where $\mathrm{x}$ stands for a Pt site. Subsequently, adsorbed residues must react with an O-containing species (out of water) to form $\mathrm{CO}_{2}$ :

$\mathrm{H}_{2} \mathrm{O}+\mathrm{Pt} \rightarrow \mathrm{Pt}(\mathrm{OH})+\mathrm{H}^{+}+\mathrm{e}^{-}$
$\mathrm{CO}+\mathrm{Pt}(\mathrm{OH}) \rightarrow \mathrm{CO}_{2}+\mathrm{H}^{+}+\mathrm{e}^{-}$

For reactions 1-4, $\mathrm{Pt}$ is the best known catalyst. However, $\mathrm{OH}$ formation at $\mathrm{Pt}$, reaction 5 begins, slowly, at potentials above $0.45-0.5 \mathrm{~V} v$ s. RHE and runs somehow faster above $0.6 \mathrm{~V}$. But considering that the $\mathrm{O}_{2}$ cathode $\left(\mathrm{E}_{\mathrm{o}}=1.23 \mathrm{~V}\right)$ presents actual potential values below 0.8 $0.7 \mathrm{~V}$, an anodic potential of $0.6 \mathrm{~V}$ is much too high for FC application. Carbon monoxide and other residues remain unoxidized at the surface, cause a blockage of active sites and impede further reaction. These kind of problems are the center of interest of electrocatalysis. Electrocatalysis studies are thus directed to: establishing the nature of the species formed during adsorption, understanding the mechanism of reaction, studying surface structural effects, searching for new catalysts, etc.

Alcohols and other small organic molecules $(\mathrm{HCOH}$, $\mathrm{HCOOH}$ ) undergo complex parallel pathways during oxidation. Therefore the study of alcohol oxidation process requires a multidisciplinary approach. With the application of spectroscopic and microscopic methods in electrocatalysis, considerable progress has been achieved in the last years. In the following sections some examples of the use of these methods are presented, showing how they contributed to the present knowledge of methanol oxidation reaction.

\section{The Electrochemical Interface. Effect of Interfacial Water in Electrocatalysis}

Over many years in the past, electrochemists have devoted much effort to studying the double layer. A lot of experimental studies, particularly at $\mathrm{Hg}$ electrodes, have contributed to elaborate a model of the electrochemical interface, which was able to explain the results of charge and capacitance measurements and their dependence on the electrolyte composition and on the applied potential., ${ }^{4,5}$ The use of infrared spectroscopy is contributing today to achieve a molecular view of the electrochemical interface. Thus, the nature and the state of several specifically adsorbed anions on well defined single crystal electrodes have been deduced via analysis of FTIR spectroscopic data. ${ }^{5}$ Although interpretation of the spectra is still a matter of discussion, molecular level data are of very much value in giving a more reliable picture of the double layer. 
The state of anions at the interface and the state of adsorbed water as well, are two issues of paramount importance in electrocatalysis. Data of infrared spectra for adsorbed water at $\operatorname{Pt}(111)^{6,7}$ have been interpreted in terms of an increasing interaction of water molecules with the metal surface, as the electrode potential is made more positive in the region above $c a$. $0.45 \mathrm{~V} v s$. RHE. It has been reported that adsorption of water takes place with participation of the non-bonding molecular orbitals, $3 \mathrm{a}_{1}$ and $1 b_{1}$ (Figure $\left.3 a\right) .{ }^{8}$ Inspection of the form of these orbitals indicates that the $1 b_{1}$ orbital sets the molecular plane parallel and the $3 \mathrm{a}_{1}$ orbital perpendicular to the substrate surface. In the absence of external forces, as in the case of adsorption in UHV, the actual situation is a compromise between both positions, i.e., the molecular plane is inclined forming an angle of $55^{\circ}$ with the substrate. Such position allows the formation of $\mathrm{H}$-bridges as shown in Figure $3 \mathrm{~b}$, giving rise to the ice-like structure observed in UHV. At the electrochemical interface, however, the high electric

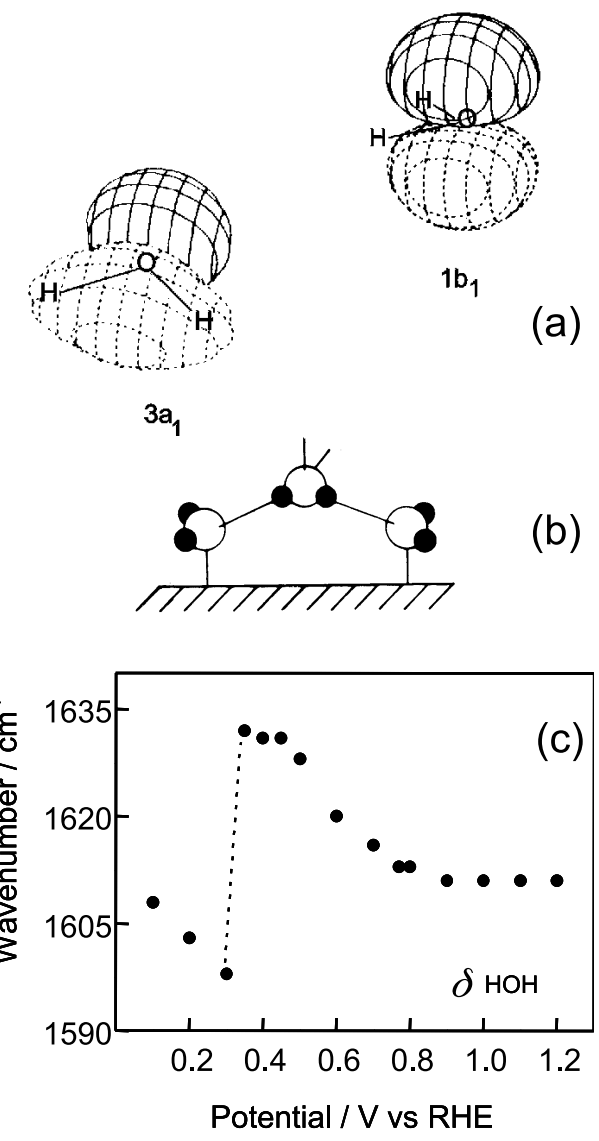

Figure 3. (a) Molecular orbitals of water after Jorgensen and Salem; ${ }^{9} 3 a_{1}$ and $1 b_{1}$ orbitals are used in bonding to surfaces. (b) Schematic representation showing $\mathrm{H}$-bonded water molecules adsorbed on a solid surface, as suggested for a $\mathrm{Pt}(111)$ electrode in UHV. ${ }^{8}(\mathrm{c})$ Potencial dependence of the band center frequency for the bending mode of water, taken from in situ FTIR reflectance spectra. Pt(111) electrode in $0.1 \mathrm{~mol} \mathrm{~L}^{-1} \mathrm{HClO}_{4}$ solution. ${ }^{7}$ field causes a preferential orientation the water dipole, forcing the molecules into a perpendicular position. In this way, participation of the $3 \mathrm{a}_{1}$ orbital is favored. This effect was detected by monitoring the infrared band for the bending mode of water in spectra obtained at $\operatorname{Pt}(111)$ in $\mathrm{HClO}_{4}$ solutions. ${ }^{7}$ Electrons of the $3 \mathrm{a}_{1}$ orbital occupy the region between the two hydrogen atoms, acting as a shield between their nuclei. However, when these electrons participate in the bonding to the surface, the electron density between the protons diminishes and the repulsion between them increases. The resulting bond angle is wider as shown by the frequency shift of the bending mode at potentials above $0.45 \mathrm{~V}$ (Figure $3 \mathrm{c}$ ). Such behavior of water has clear consequences for the oxidation of organic substances. ${ }^{10}$

Water molecules constitute the main population of the interface, so that each metal atom is probably covered with a water molecule. Therefore, the adsorption processes of an organic molecule in aqueous media must be considered as a water replacement reaction:

$\mathrm{Pt}\left(\mathrm{H}_{2} \mathrm{O}\right)_{\mathrm{ad}}+\mathrm{CH}_{3} \mathrm{OH}_{\text {sol }} \rightarrow \mathrm{Pt}\left(\mathrm{CH}_{3} \mathrm{OH}\right)_{\mathrm{ad}}+\mathrm{H}_{2} \mathrm{O}_{\text {sol }}$

In Table 1 it can be observed that the adsorption energy of several small organic molecules and water are of the same order magnitude. Thus, it can be stated that organic species compete with water for adsorption sites. An increasing $\mathrm{H}_{2} \mathrm{O}$-metal interaction, as deduced above from the shift of the bending mode in IR spectra, has a negative effect in the adsorption step (7). This competition is responsible for the decay in current observed during the oxidation of small organic molecules ${ }^{10}$ in the region of potentials between $0.4 \mathrm{~V}$ and $0.7 \mathrm{~V}$. The cyclic voltammogram of $\mathrm{HCOOH}$ at $\mathrm{Pt}(111)$ is presented in Figure $4 \mathrm{a}$ and $4 \mathrm{~b}$, to illustrate this phenomenon. The current maxima observed in the cyclic voltammograms for small organic molecules are not caused by the interplay between diffusion and activation as expected for CV's of soluble substances. ${ }^{12}$ They are produced by some inhibiting surface process, (as e.g., stronger interaction of water with the $\mathrm{Pt}$ surface as explained above). Such a process is reversible

Table 1. Experimental data for thermal desorption of water and some organic species at $\operatorname{Pt}(111)^{11}$

\begin{tabular}{ccc}
\hline Substance & $\begin{array}{c}\text { Temperature at } \\
\text { desorption } \\
\text { maximum / K }\end{array}$ & $\begin{array}{c}\text { Desorption } \\
\text { energy/ } \mathrm{kJ} \mathrm{mol}^{-1}\end{array}$ \\
\hline $\mathrm{H}_{2} \mathrm{O}$ & $170-180$ & 42 \\
$\mathrm{CH}_{3} \mathrm{OH}$ & 190 & 46 \\
$\mathrm{HCOOH}$ & 170 & 42 \\
$\mathrm{C}_{2} \mathrm{H}_{5} \mathrm{OH}$ & 200 & 46 \\
\hline
\end{tabular}



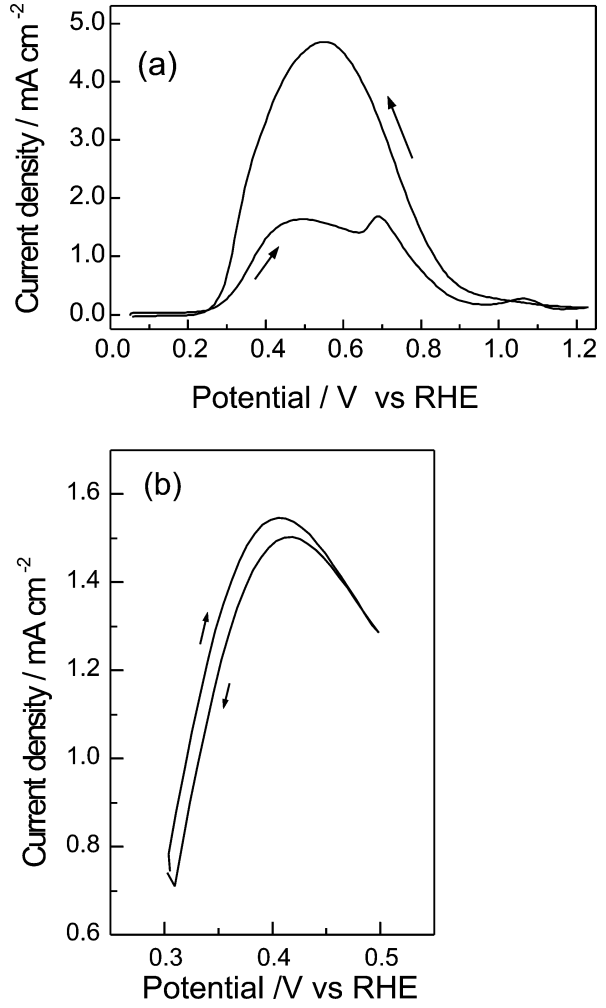

Figure 4. (a) Cyclic Voltammograms of a single crystal Pt (111) electrode in $1 \mathrm{~mol} \mathrm{~L} \mathrm{~L}^{-1} \mathrm{HCOOH} / 0.1 \mathrm{~mol} \mathrm{~L}^{-1} \mathrm{HClO}_{4}$. Sweep rate $0.05 \mathrm{~V} \mathrm{~s}^{-1}$. (b) As in (a) but reversing the potential scan at $0.5 \mathrm{~V}^{10}$

with potential and therefore a re-activation (positive currents) is observed during the negative going potential sweep of the voltammogram. Note that for $\mathrm{HCOOH}$, the effect is observed even if the potential is reversed at $0.5 \mathrm{~V}$, i.e., a potential where the surface does not become free of poisons and is not covered with oxides (Figure 4b).

\section{The Products of Alcohol Oxidation}

Using the method of on line mass spectrometry, also called DEMS (Differential Electrochemical Mass Spectrometry), it is possible to detect on line volatile reaction products during the application of a potential scan. ${ }^{13}$ The advantage of the method for studying electrocatalysis of alcohol oxidation is illustrated for ethanol in Figure 5. Signals for the oxidation products, carbon dioxide and acetaldehyde, are shown; isotope labeled ethanol, $\mathrm{C}_{2} \mathrm{D}_{5} \mathrm{OD}$, was used in this experiment to increase the mass of acetaldehyde, which otherwise coincides with that of $\mathrm{CO}_{2}$. Note that $\mathrm{CO}_{2}$ is formed in a limited region of potentials, while acetaldehyde, is the main product in the whole region of potentials, including the reverse cycle.

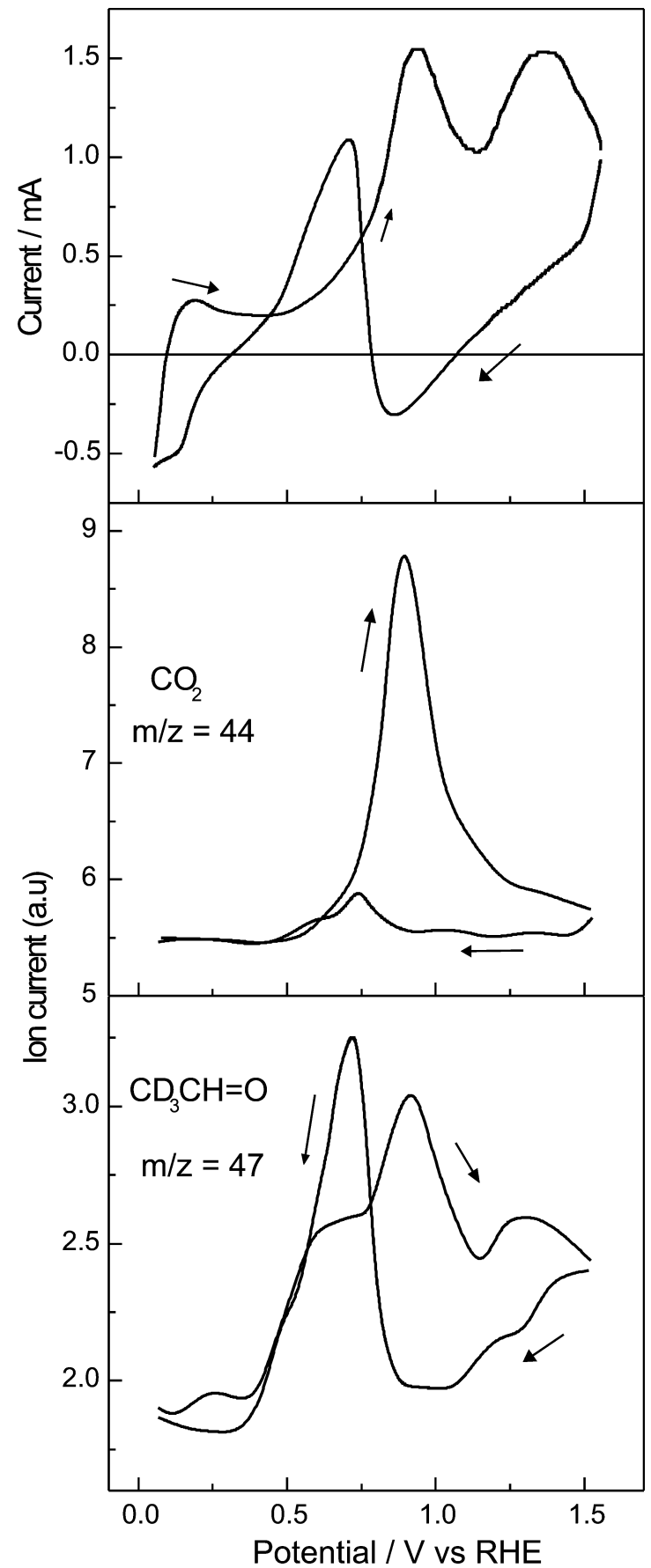

Figure 5. On line mass spectrometry (DEMS) experiments during the oxidation of ethanol on a porous Pt electrode. Current and mass signals for $\mathrm{CO}_{2}$ and acetaldehyde, during a cyclic voltammogram in $0.01 \mathrm{~mol} \mathrm{~L}^{-1} \mathrm{C}_{2} \mathrm{D}_{5} \mathrm{OD}+0.05 \mathrm{~mol} \mathrm{~L}^{-1} \mathrm{H}_{2} \mathrm{SO}_{4}$. Sweep rate: $10 \mathrm{mV} \mathrm{s}^{-1}$.

In the case of methanol oxidation, the DEMS method shows formation of $\mathrm{CO}_{2}$ (main product) and methyl formate. The latter is formed in a homogeneous reaction between formic acid and methanol:

$\mathrm{HCOOH}+\mathrm{CH}_{3} \mathrm{OH} \rightarrow \mathrm{HCOOCH}_{3}$ 


\section{Structural Effects in Methanol Oxidation}

Cyclic voltammograms during methanol oxidation on the three low index faces ((111), (110) and (100)) of singlecrystal Pt electrodes exhibit characteristic responses as shown in Figure $6 .{ }^{14}$ These experiments clearly demonstrate that methanol oxidation is a surface sensitive reaction. In this respect it must be stressed that both adsorption of methanol and oxidation of the adsorbed residues are affected by the surface structure. This was established via in situ FTIR spectra taken during methanol oxidation at $\mathrm{Pt}(100), \operatorname{Pt}(111)$ and $\mathrm{Pt}(110)$ as shown in Figure 7. Besides the bands for $\mathrm{CO}_{2}$ at $2341 \mathrm{~cm}^{-1}$, the spectra exhibit features corresponding to linear and bridge bonded $\mathrm{CO}$ at $\mathrm{ca}$. $2060 \mathrm{~cm}^{-1}$ and $1850 \mathrm{~cm}^{-1}$ respectively. Also, bands for an adsorbed $(\mathrm{COH})$ species is seen at ca $1260 \mathrm{~cm}^{-1}$ and the $\mathrm{C}-\mathrm{H}$ stretching of other hydrogenated species (as, e.g. $\mathrm{H}_{2} \mathrm{COH}$ ) is observed at $3000 \mathrm{~cm}^{-1}$. The integrated band intensities for $\mathrm{CO}$ and $\mathrm{CO}_{2}$ given in Figure 8, show the different behavior of these surfaces. Clearly, Pt(110) adsorbs methanol forming $\mathrm{CO}$ at lower potentials than $\mathrm{Pt}(111)$ or $\mathrm{Pt}(100)$. However, $\mathrm{CO}_{2}$ formation is the same for both these surfaces, indicating that in the potential region below, say, $0.55 \mathrm{~V}$, the adsorption of methanol is not the rate determining step of the oxidation process. $\mathrm{Pt}(100)$, on the other hand, remains poisoned by the adsorbed species up to higher potentials. ${ }^{14}$

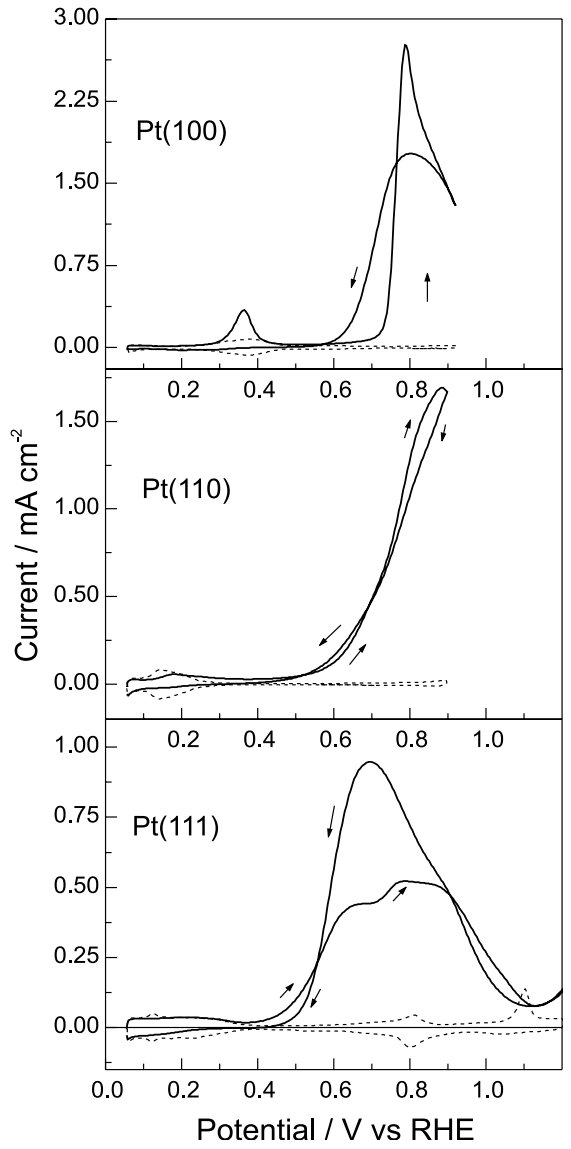

Figure 6. First potential scan for methanol oxidation on $\mathrm{Pt}(\mathrm{hkl})$. $1.0 \mathrm{~mol} \mathrm{~L}^{-1} \mathrm{CH}_{3} \mathrm{OH}$ in $1.0 \mathrm{~mol} \mathrm{~L}^{-1} \mathrm{HClO}_{4}$; sweep rate $=50 \mathrm{mV} \mathrm{s}^{-1} .^{14}$
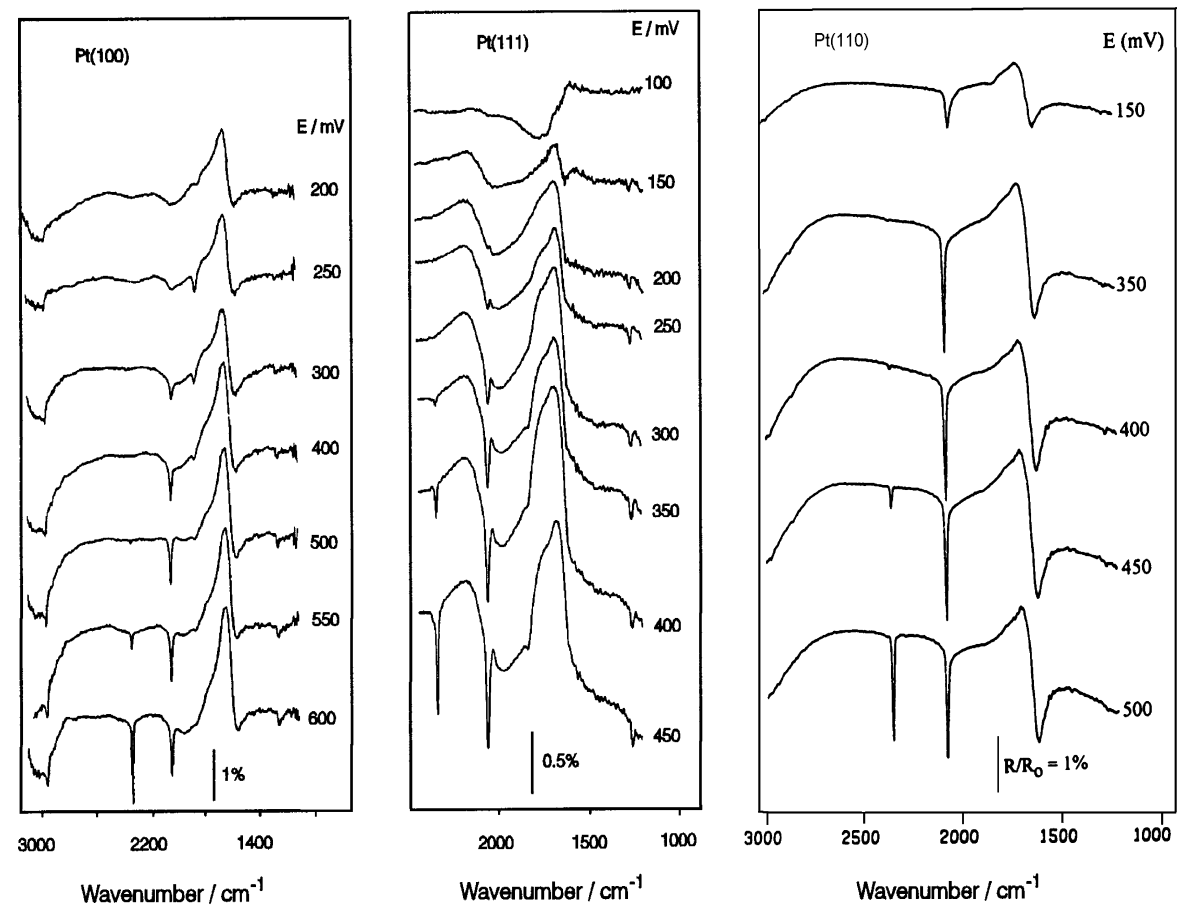

Figure 7. Infrared spectra in $1.0 \mathrm{~mol} \mathrm{~L}^{-1} \mathrm{CH}_{3} \mathrm{OH}$ in $1.0 \mathrm{~mol} \mathrm{~L}^{-1} \mathrm{HClO}_{4}$ at $\mathrm{Pt}(100), \mathrm{Pt}(111)$ and $\mathrm{Pt}(110)$. Reference spectra collected at $50 \mathrm{mV}$; sample spectra collected at the indicated potentials. ${ }^{14}$ 

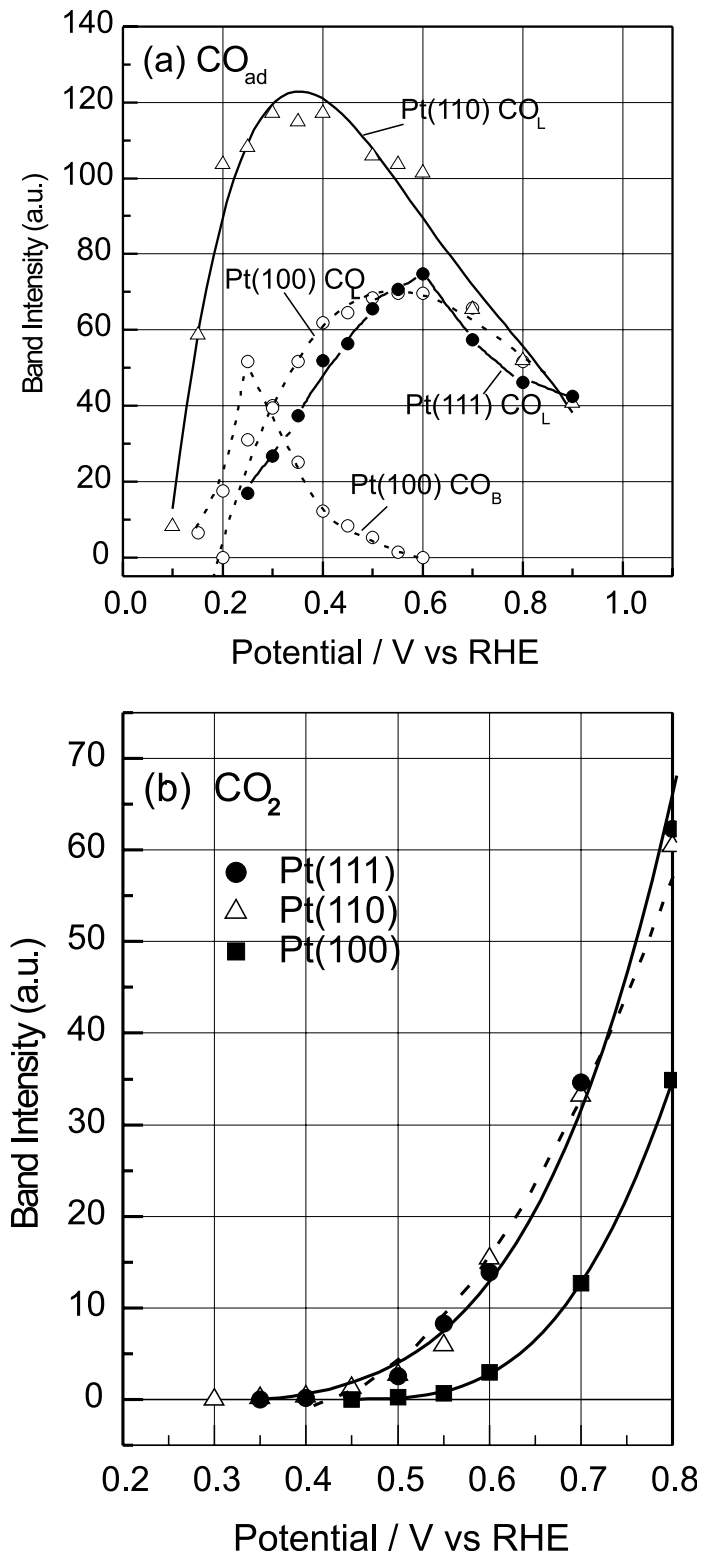

Figure 8. Integrated band intensities from IR spectra at $\operatorname{Pt}(111)$, $\mathrm{Pt}(100)$ and $\mathrm{Pt}(110)$ in $1.0 \mathrm{~mol} \mathrm{~L}^{-1} \mathrm{CH}_{3} \mathrm{OH}+0.1 \mathrm{~mol} \mathrm{~L}^{-1} \mathrm{HClO}_{4}$. (a) linear $\left(\mathrm{CO}_{\mathrm{L}}\right)$ and bridge $\left(\mathrm{CO}_{\mathrm{B}}\right)$ bonded carbon monoxide; (b) carbon dioxide.

\section{Promotion of the Catalysis of Alcohol Oxidation}

As pointed out in the introduction the main problem of methanol reaction is that $\mathrm{Pt}$ is not able to dissociate water and hence to oxidize the adsorbed organic residues at low potentials. Therefore, several binary combinations of Pt and other metals have been suggested as catalysts: $\mathrm{PtRu}, \mathrm{PtMo}$, PtOs, PtSn etc. ${ }^{15}$ From these, PtRu presents the best performance. ${ }^{16,17}$ As an explanation for the promotion of methanol oxidation a so-called bi-functional mechanism is invoked, ${ }^{18}$ according to which, Pt adsorbs and dissociates methanol (reactions 1-4) producing $\mathrm{CO}_{\mathrm{ad}}$ and $\mathrm{Ru}$ foms $\mathrm{Ru}(\mathrm{OH})_{\text {ad }}$ thus producing the corresponding reaction (5) at lower potentials than Pt.

$\mathrm{PtRu}$ catalysts have been prepared in different forms: alloys, ${ }^{16,17}$ electrodeposits of $\mathrm{Pt}$ and $\mathrm{Ru},{ }^{19}$ adsorption of $\mathrm{Ru}$ on $\mathrm{Pt}^{16}$ etc. Although all these materials present catalytic properties towards methanol oxidation, they do not have the same activity. The elucidation of the reason for these differences was necessary for optimizing the catalyst preparation. Due to the preferential segregation of $\mathrm{Pt}$ on the surface of alloys, the best method for pre-treating this material is via sputtering in UHV in order to have the same composition of the alloy on the surface as in the bulk of the metal. ${ }^{20} \mathrm{~A}$ further advantage of this treatment is that the resulting surfaces are smooth as shown by a comparison of cyclic voltammograms for $\mathrm{Pt}(111)$ and for the alloys, measured in $\mathrm{HClO}_{4}{ }^{21}$ Alloy electrodes treated in UHV have current densities of the same order as $\operatorname{Pt}(111)$, showing that the roughness factors are close to unity. ${ }^{21}$ The catalytic activity was studied by measuring the current at constant potential using alloys prepared in UHV and also $\mathrm{Pt}(111) /$ Ru electrodes prepared by adsorbing Ru onto Pt(111). The results are shown in Figure $9 \mathrm{a}$ and $9 \mathrm{~b}$. The current-time curves, Figure 9a, were measured after applying a potential step from $0.05 \mathrm{~V}$ to $0.50 \mathrm{~V} v s$. RHE. The current after a given time (see figure caption) is plotted in Figure 9b, for several $\mathrm{Ru}$ coverages. We observe that alloys present the best performance for the reaction. Obviously, the bi-functional effect works at best on surfaces having an optimum distribution of $\mathrm{Pt}$ and $\mathrm{Ru}$ atoms as in the case of the alloys. Scanning tunneling microscopy of $\mathrm{Pt}(111) / \mathrm{Ru}$ electrodes prepared by adsorption of $\mathrm{Ru}$ onto $\mathrm{Pt}(111)$ show that $\mathrm{Ru}$ is not homogeneously distributed on the surface, but forming islands. ${ }^{16,21}$ Also, in PtRu materials prepared in UHV by evaporating $\mathrm{Ru}$ onto $\mathrm{Pt}(111), \mathrm{Ru}$ is deposited in form of islands presenting two or more layers. The triangular form of the two-layer clusters observed in Figure 10 correspond to the initial steps of formation of hexagonal Ru crystals. Thus, the effect seems to have a thermodynamic ground: the interaction energy between $\mathrm{Ru}$ atoms is probably higher than between Pt and Ru. Obviously, in this kind of material oxidation of $\mathrm{CO}_{\mathrm{ad}}$ can occur only at the borders of such structures.

An interesting structural effect of the PtRu materials is also observed during the oxidation of ethanol on PtRu catalysts. Figure 11 shows spectra using two electrodes, a smooth Pt:Ru (1:1) alloy and a rough electrodeposit of PtRu prepared out of a solution having the same composition ratio, and consequently, about the same surface composition. IR bands in the region $1200-1400 \mathrm{~cm}^{-1}$ belong 

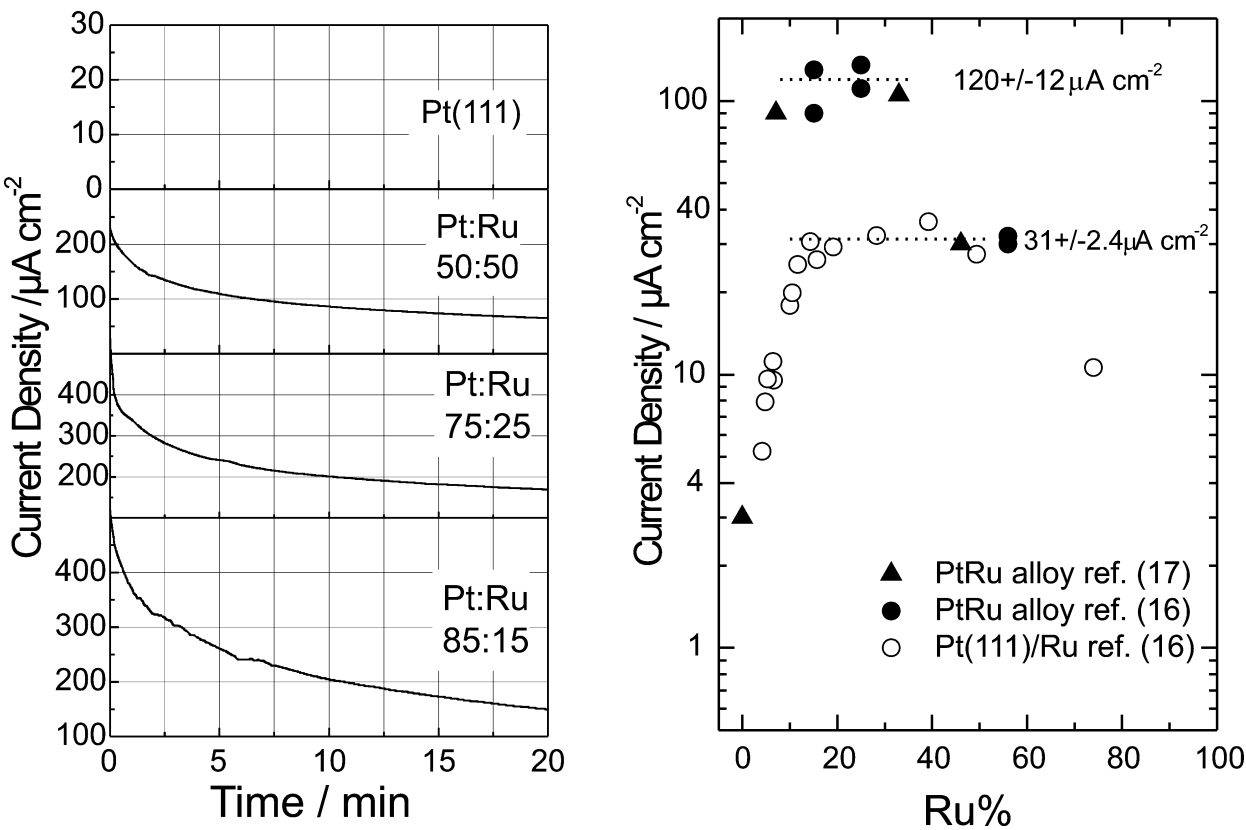

Figure 9. Left: current-time curves, comparing the catalytic activity of $\mathrm{Pt}(111)$ and $\mathrm{PtRu}$ alloys, towards methanol oxidation in 0.5 mol $\mathrm{L}^{-1}$ $\mathrm{CH}_{3} \mathrm{OH}+0.1 \mathrm{~mol} \mathrm{~L}^{-1} \mathrm{HClO}_{4}$. Potential $0.5 \mathrm{~V} v$ s. RHE. Room temperature. Right: plot of the current density for methanol oxidation at $0.5 \mathrm{~V}$, as function of Ru coverage. Data for UHV prepared PtRu alloys, obtained at $20 \mathrm{~min}$; data for $\mathrm{Pt}(111) / \mathrm{Ru}$ formed by spontaneous adsorption, measured after 5min. Solutions: $0.5 \mathrm{~mol} \mathrm{~L}^{-1} \mathrm{H}_{2} \mathrm{SO}_{4}+0.5 \mathrm{~mol} \mathrm{~L}^{-1} \mathrm{CH}_{3} \mathrm{OH}^{17} ; 0.5 \mathrm{~mol} \mathrm{~L}^{-1} \mathrm{CH}_{3} \mathrm{OH}+0.1 \mathrm{~mol} \mathrm{~L}^{-1} \mathrm{HClO}_{4}{ }^{16}$

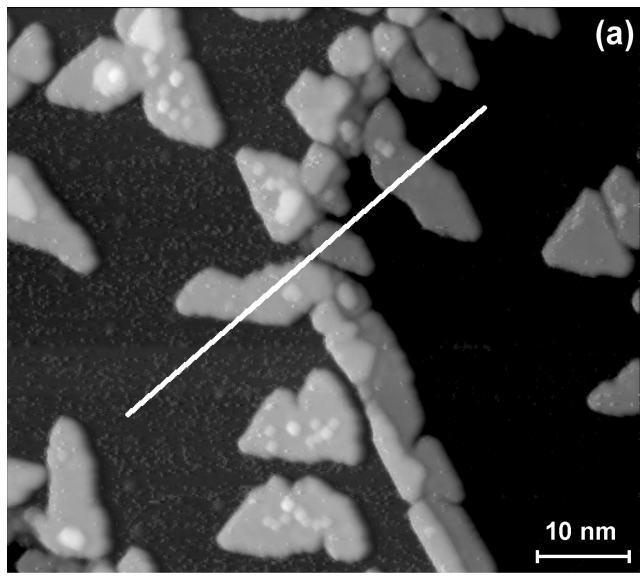

profile along white line

(b)

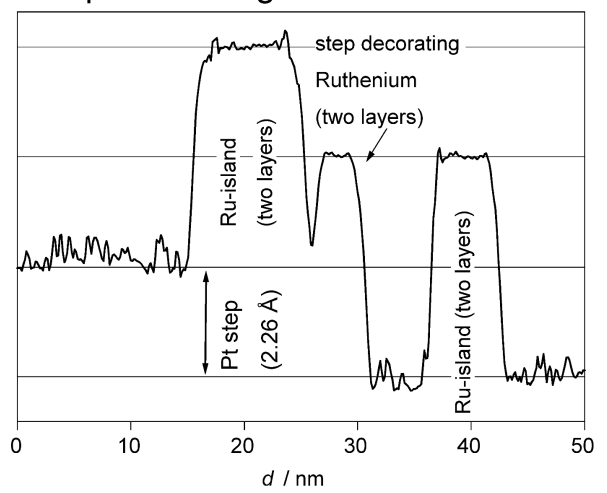

Figure 10. STM micrographs (a) and profile (b) along the marked line for $\mathrm{Ru}$ deposited onto $\mathrm{Pt}(111)$ via evaporation in UHV. Island form shows the beginning of Ru crystallization (hexagonal) ${ }^{22}$
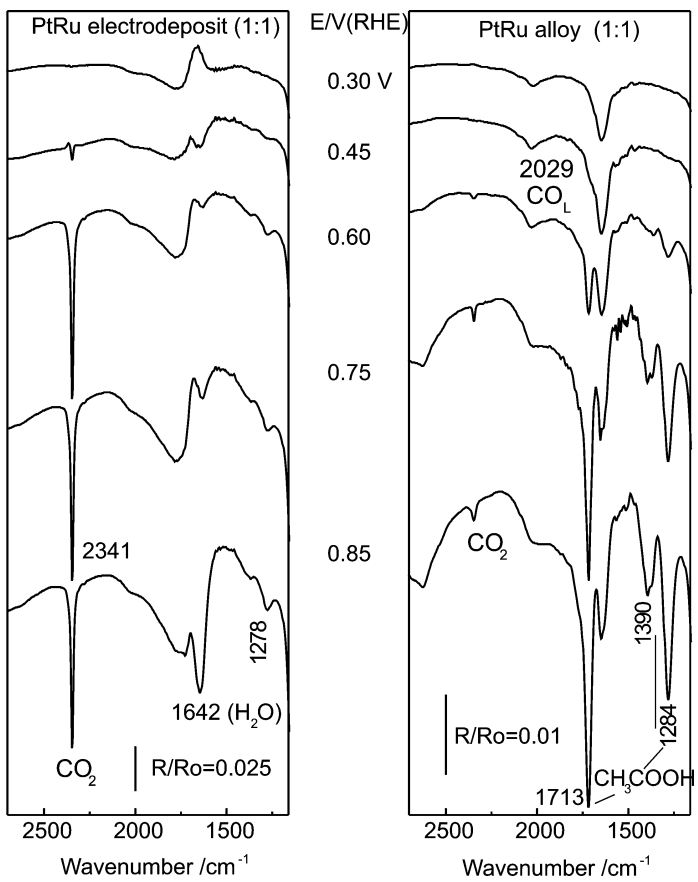

Figure 11. FTIR reflectance spectra during oxidation of $0.1 \mathrm{~mol} \mathrm{~L}^{-1}$ $\mathrm{C}_{2} \mathrm{H}_{5} \mathrm{OH}$ in $0.1 \mathrm{~mol} \mathrm{~L}^{-1} \mathrm{HClO}_{4}$, using a (1:1) PtRu alloy and a (1:1) PtRu electrodeposit on a gold substrate. Note the differences in the ratio of the bands for $\mathrm{CO}_{2}\left(2341 \mathrm{~cm}^{-1}\right)$ and acetic acid (bands at $1284 \mathrm{~cm}^{-1}, 1390 \mathrm{~cm}^{-1}$ and $\left.1717 \mathrm{~cm}^{-1}\right)$. 
to the product acetic acid and the band at $1700 \mathrm{~cm}^{-1}$ is due to both, acetic acid and acetaldehyde. The feature at 2341 $\mathrm{cm}^{-1}$ corresponds to $\mathrm{CO}_{2}$, i.e., this band indicates a breaking of the $\mathrm{C}-\mathrm{C}$ bonding. It can be clearly observed, that the yield ratio $\mathrm{CO}_{2} / \mathrm{C}-\mathrm{C}$ products is higher in the case of the electrodeposit than in the alloy. The main conclusion here is that there is a higher capability of the rough electrode to breaking the $\mathrm{C}-\mathrm{C}$ bonding.

\section{Use of UHV Methods in Electrocatalysis Studies}

Besides the use of a sputtering procedure to clean alloys in order to reach a reproducible composition, as described before, a UHV chamber can be used to prepare catalysts by evaporation of the components onto appropriate inert substrates or to perform surface analysis on clean or modified electrodes. Taking into account that during its transfer and analysis in UHV the electrode is no more under potential control, the surface can be easily contaminated and therefore, this approach can be done only if the electrochemical cell is mounted on line with the UHV system. Thus, after producing some reaction in the electrochemical cell, the electrode can be transferred directly to the lock chamber of the UHV system, Figure 12a.

a)

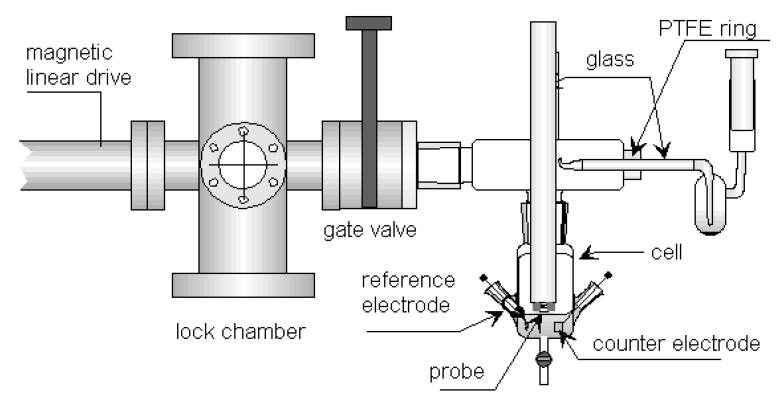

b)

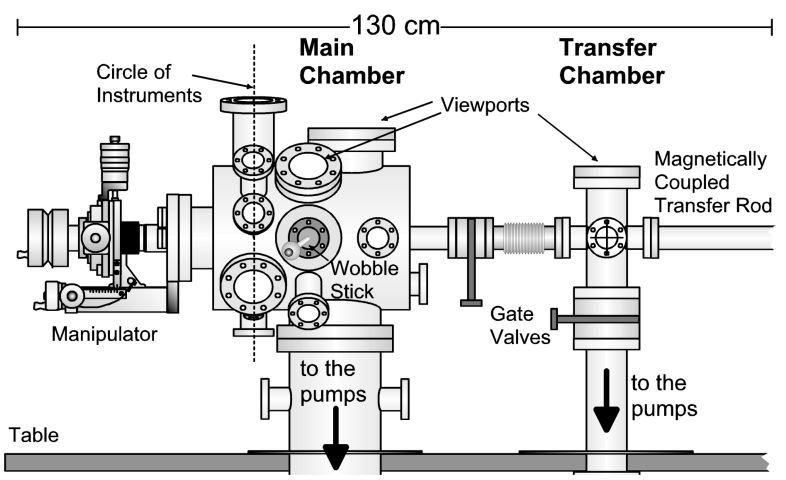

Figure 12. (a) Electrochemical cell coupled on line with the lock chamber of a UHV equipment. (b) Main chamber of the UHV system for surface analysis.

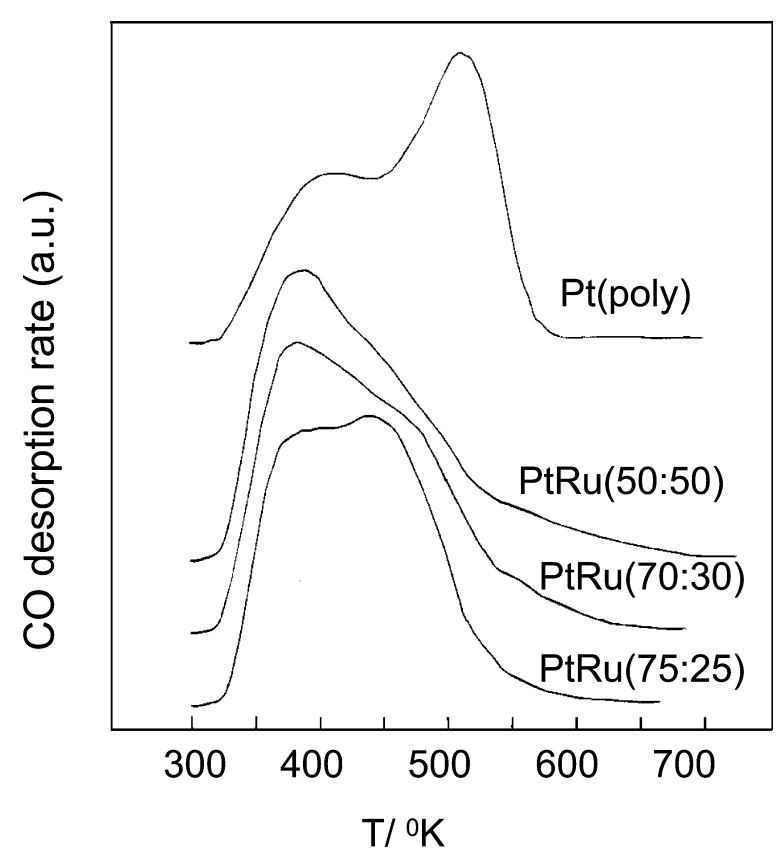

Figure 13. Thermal desorption spectra for carbon monoxide on polycrystalline $\mathrm{Pt}$ and $\mathrm{Pt} / \mathrm{Ru}$ alloys. Alloy compositions as indicated.

After a rapid evacuation in the lock chamber $\left(10^{-6}\right.$ mbar $)$, the electrode is transferred to the main chamber Figure $12 \mathrm{~b}$, which stays permanently under a vacuum of $10^{-9}$ to $10^{-10}$ mbar. There, different surface analysis methods can be performed. As an example, we show in Figure 13 thermal desorption spectra (TDS) of carbon monoxide adsorbed on different PtRu catalysts. Two adsorption states are observed at Pure polycrystalline Pt, which are shifted to lower temperature in the PtRu alloys. This indicates a lowering of the adsorption energy for $\mathrm{CO}$ on these materials. Thus, it can be concluded that the concept of $\mathrm{Ru}$ acting as a promoter for methanol oxidation according to a bi-functional mechanism only, needs to be revised. A lowering of the adsorption energy of $\mathrm{CO}$ on PtRu materials can also contribute to the observed catalytic effects.

\section{Conclusions}

Oxidation of small organic molecules have a strong dependence on the structure of the catalyst surface. The state of water at the interface plays an important role in the oxidation process. Water is on one side the oxygen donor species necessary for oxidation of alcohols to $\mathrm{CO}_{2}$, but, on the other side, it is also a competitor with organic molecules for adsorption sites. As a result of this dual behavior one observes anodic current maxima in the positive and negative going directions of the voltammograms. 
Alcohol oxidation is a complex process affected by the nature and structure of the electrode surface and its interfacial properties as well. Surface poisoning by adsorbed $\mathrm{CO}$ formed during alcohol adsorption leads to a deactivation of the electrode surface. Binary catalysts, in particular PtRu, contribute to alleviate the consequences of surface poisoning by forming adsorbed $\mathrm{OH}_{\mathrm{ad}}$ at low potential, thus facilitating CO oxidation. Moreover, TDS data show that $\mathrm{CO}$ molecules are less strongly adsorbed at the PtRu catalyst than at pure Pt, this being an additional cause for lowering its oxidation potential.

In situ, ex situ and on line spectroscopic and microscopic methods have strongly contributed to the understanding of electrocatalysis of alcohol oxidation.

\section{Ackonowledgments}

Financial support from FAPESP and CNPq is gratefully acknowledged.

\section{References}

1. Vielstich, W; Fuel Cells, Wiley Interscience, Bristol, 1965; Vielstich, W; Iwasita, T. In Handbook of Heterogeneous $\mathrm{Ca}$ talysis; Ertl, G.; Knözinger, H.; Weitkamp, J. eds.; Verlag Chemie: Weinheim, 1997, vol 4 p. 2090.

2. Iwasita-Vielstich, T. In Advances in Eletrochemical Science and Engineering; Gerischer, H.; Tobias, Ch. W. eds.; Verlag Chemie: Weinhein, 1990, vol. 1, p. 127.

3. Bagotzki,V.S.; Vassiliev, Yu. B.; Kazova, O. A.; J. Electroanal. Chem. 1977, 81, 229.

4. Delahay, P.; Double Layer and Electrode Kinetics, Interscience Publishers, John Wiley \& Sons: New York, 1965.

5. Habib, M. H. In Modern Aspects of Electrochemistry; Bockris, J. O’M.; Conway, B. E. eds., Plenum: New York, 1977, vol 12.

6. Iwasita, T; Nart, F.C. In Progress in Surf. Sci.; Davison, S.G., ed.; Pergamon: Great Britain, 1997, vol. 55, p. 271.

7. Xia, X. H.; T. Iwasita, T.; J. Electroanal. Chem. 1996, 411, 95.
8. Thiel, P. A. ; Madey, T. E.; Surf. Sci. Rep. 1987, 7, 211.

9. Jorgensen, W. L.; Salem, L.; The Organic Chemist's Book of Orbitals, Academic Press: New York, 1973.

10. Iwasita, T.; Xia, X.H.; Liess, H.-D.; Vielstich, W.; J. Phys. Chem. B 1997, 101, 7542.

11. Iwasita, T.; Pastor, E. In Interfacial Electrochemistry. Theory, Experimental and Applications; A. Wieckowski, ed; Marcel Dekker: New York, 1999, p. 353.

12. Bard, A.;. Faulkner, L; Electrochemical Methods. Fundamentals and Applications, John Wiley and Sons Inc.: New York, 2001.

13. Bittins-Cattaneo, B; Cataneo, E.; Königshoven, P; Vielstich, W. In Electroanalytical Chemistry a Series of Advances; Bard, A. J. ed, Marcel Dekker: New York 1991, p.181.

14. Xia, X. H.; Iwasita, T.; Ge, F.; Vielstich, W.; Electrochim. Acta 1996,41, 711.

15. Hamnett, A. In Interfacial Electrochemistry. Theory, Experimental and Applications; A. Wieckowski ed., Marcel Dekker: New York, 1999, p. 843.

16. Iwasita, T.; Hoster, H.; John-Anacker, A.; Lin, W. F.; Vielstich, W; Langmuir 2000,16, 522.

17. Gasteiger, H.A.; Markovic, N.; Ross, P. N.; Cairns, E. J.; J. Electrochem.Soc. 1994, 141, 1795.

18. Watanabe, M.; Motoo, S.; J. Electroanal. Chem. 1976, 69, 429.

19. Krausa M.; Vielstich, W.; J. Electroanal. Chem., 1994, 379, 307.

20. Gasteiger, H. A.; Ross, P. N.; Cairns, E. J.; Surf. Sci. 1993, $293,67$.

21. Hoster, H.; Iwasita, T.; Baumgärtner, H.; Vielstich, W.; J. Electrochem.Soc. 2001, 148, A496.

22. Hoster, H.; Iwasita, T.; Baumgärtner, H.; Vielstich, W.; Phys. Chem. Chem. Phys. 2001, 3, 337.

Received: March 5, 2002

Published on the web: August 2, 2002

FAPESP helped in meeting the publication costs of this article. 